\title{
Indeks Keragaman Serangga Hama Pada Tanaman Padi (Oryza sativa L.) Di Lahan Persawahan Padi Dataran Tinggi Desa Sukawening, Kecamatan Ciwidey, Kabupaten Bandung
}

\author{
Martua Suhunan Sianipar ${ }^{(1)}$, Luciana Djaya ${ }^{(1)}$, Entun Santosa ${ }^{(1)}$, RC.Hidayat Soesilohadi ${ }^{(2)}$, \\ W. Daradjat Natawigena ${ }^{(1)}$, Mey Priandi Bangun ${ }^{(3)}$ \\ (1). Staff Pengajar DHPT Fakultas Pertanian UNPAD. \\ (2). Staff Pengajar Fakultas Biologi UGM.
}

(3). Mahasiswa DHPT Fakultas Pertanian UNPAD.

\begin{abstract}
Abstrak
Kemampuan Indonesia dalam memenuhi kebutuhan beras nasional sangat penting. Akan tetapi, usaha pemenuhan kebutuhan beras ini tidak selamanya berjalan dengan lancar karena terganggunya produktivitas padi. Salah satu penyebab turunnya produktivitas padi di Indonesia karena adanya serangan serangga hama. Beberapa kendala yang menyebabkan gagalnya petani dalam mengendalikan serangga hama karena petani masih belum melakukan identifikasi serangga hama dan gejala serangan dengan baik. Penelitian yang dilaksanakan akhir tahun 2012 ini yang berlokasi di Lahan Persawahan Padi Dataran Tinggi Desa Sukawening, Kecamatan Ciwidey, Kabupaten Bandung, Jawa Barat bertujuan meng inventarisasi dan mendapatkan nilai keragaman jenis serangga hama pada tanaman padi. Penangkapan serangga hama yang dilakukan dengan menggunakan perangkap kuning, perangkap jaring dan perangkap cahaya. Hasil penangkapan serangga diidentifikasi di laboratorium. Indeks keragaman serangga dianalisis dengan menggunakan perhitungan Shannon- Weinner. Serangga hama yang dominan diperoleh pada fase vegetative yaitu Scirpophaga incertulas, Thaia oryzivora, dan Orselia oryzae. Serangga hama minor diperoleh yaitu Dicladispa armigera, Leptispa pygmaea, dan Melanitis ledaismene. Serangga hama yang dominan diperoleh pada fase generative yaitu Leptocorisa acuta, Scirpophaga incertulas, dan Thaiaoryzivora. Serangga hama minor diperoleh yaitu Nilaparvata lugens, Sogatella furcifera, dan Cofana spectra. Indeks keragaman serangga hama yang diperoleh pada ketiga lahan percobaan ada diantara sedang hingga tinggi.Pada fase vegetatif indeks keragaman tertinggi sebesar 4,74 pada pengamatan ke 6 dan terendah pada pengamatan ke 1 sebesar 2,22. Pada fase generatif indeks keragaman tertinggi pada pengamatan ke 9 sebesar 4,86 dan terendah pada pengamatan ke 12 sebesar 1,37 .
\end{abstract}

Kata kunci :indeks keragaman, serangga hama, padi, Kabupaten Bandung.

\section{PENDAHULUAN}

Serangga merupakan salah satu bagian dari keragaman hayati. Serangga hama adalah organisme yang menimbulkan kerusakan pada tanaman dan menurunkan kualitas maupun kuantitasnya sehingga menimbulkan kerugian ekonomi bagi manusia (Hill, 1997).

Salah satu komponen penting dalam pengendalian hama terpadu yaitu memanfaatkan musuh alami (Buchori \& Sahari, 2000). Musuh alami merupakan pengatur populasi yang efektif karena bersifat tergantung kepadatan. Jika terjadi peningkatan populasi serangga hama maka akan diikuti oleh peningkatan populasi musuh alami (respon numerik) dan respon fungisional yaitu peningkatan daya makan atau daya parasitasinya (Untung, 2006).

Indeks keragaman dapat digunakan untuk menyatakan hubungan kelimpahan spesies dalam suatu komunitas. Indeks keragaman dengan variabel yang menggolongkan struktur komunitas meliputi : jumlah spesies, kelimpahan relatif spesies (kesamaan), dan homogenitas dan ukuran dari area sampel (Anonimus, 2008). Keragaman jenis adalah sifat komunitas yang memperlihatkan tingkat keragaman jenis organisme yang ada di dalamnya (Krebs, 1978). Untuk memeroleh keragaman jenis ini diperlukan kemampuan mengenal dan membedakan jenis. Serangga sering digunakan sebagai model dalam kajian ilmu 
pengetahuan, baik murni maupun terapan karena serangga memiliki keragaman yang tinggi, baik dalam sifat-sifat morfologi, fisiologi maupun perilaku adaptasi dalam lingkungannya, dan banyaknya serangga yang terdapat di muka bumi (Jumar, 2000).

\section{BAHAN DAN METODE}

Pengambilan sampel serangga hama dan musuh alaminya dilaksanakan di lahan persawahan padi dataran tinggi di Desa Sukawening, Kecamatan Ciwidey, Kabupaten Bandung pada akhir 2012. Metode pengambilan sampel dilakukan dengan metode nisbi yaitu dengan menggunakan alat-alat perangkap (perangkap jaring, perangkap kuning berperekat, dan perangkap cahaya) untuk serangga-serangga terbang. Lahan untuk pengamatan ditentukan 3 petak lahan yang dipilih secara acak. Luasan tiap lahan sekitar $15 \times 20 \mathrm{~m}^{2}$. Pengambilan sampel dilakukan satu minggu sekali. Pengamatan yang dilakukan meliputi penghitungan jumlah serangga yang tertangkap di sejumlah titik yang ditentukan.

Data yang diperoleh pada setiap penangkapan dihitung dan diidentifikasi kemudian dianalisis dengan penghitungan indeks keragaman jenis serangga menurut Shanon Weaner (Krebs, 1978). Dimana Kriteria indeks keragaman (H) menurut Odum (1971) adalah :

$>$ Keragaman jenis rendah bila $\mathrm{H}<1$

$>$ Keragaman jenis sedang bila $1 \leq \mathrm{H} \leq 3$

Keragaman jenis tinggi bila $\mathrm{H}>3$

\section{RESULT AND DISCUSSIONS}

1. Serangga Hama yang Tertangkap pada Fase Vegetatif di Lahan Padi

Hasil tangkapan dari 5 plot sampel pengamatan di lahan percobaan dengan perangkap kuning, cahaya, dan jaring pada fase vegetatif sebanyak 1104 ekor dapat dilihat pada Tabel 1.

Tabel 1. Jenis dan Jumlah Serangga Hama yang Tertangkap dengan Perangkap Kuning, Cahaya, dan Jaring pada Lahan Padi Sawah fase Vegetatif Dataran tinggi di desa Sukawening, Kecamatan Ciwidey

\begin{tabular}{|c|c|c|c|c|c|c|c|c|c|}
\hline \multirow[t]{2}{*}{ No. } & \multicolumn{3}{|c|}{ Serangga hama } & \multicolumn{6}{|c|}{ Jumlah Serangga pada Plot } \\
\hline & Ordo & Famili & Spesies & 1 & 2 & 3 & 4 & 5 & $\sum$ \\
\hline 1. & Homoptera & Cicadellidae & $\begin{array}{l}\text { Nephotettix } \\
\text { virescens }\end{array}$ & 11 & 19 & 27 & 29 & 8 & 96 \\
\hline 2. & & & Recilia dorsalis & 2 & 5 & 5 & 10 & 3 & 32 \\
\hline 3. & & & Thaia oryzivora & 20 & 46 & 38 & 42 & 13 & 164 \\
\hline 4. & & & Cofana spectra & 1 & 3 & 9 & 3 & 3 & 19 \\
\hline 5. & & Delphacidae & $\begin{array}{l}\text { Nilaparvata } \\
\text { lugens }(x x)\end{array}$ & 1 & 2 & 6 & 3 & 0 & 12 \\
\hline 6. & & & Sogatella fucifera & 2 & 3 & 10 & 9 & 0 & 24 \\
\hline 7. & Lepidoptera & Pyralidae & $\begin{array}{l}\text { Scirpophaga } \\
\text { incertulas }\end{array}$ & 18 & 56 & 38 & 53 & 20 & 198 \\
\hline 8. & & & $\begin{array}{l}\text { Cnaphalocrosis } \\
\text { medinalis }\end{array}$ & 4 & 18 & 18 & 27 & 6 & 71 \\
\hline 9. & & & $\begin{array}{l}\text { Melanitis leda } \\
\text { ismene }\end{array}$ & 1 & 1 & 6 & 1 & 2 & 11 \\
\hline 10. & Diptera & Muscidae & Atherigona spp & 22 & 21 & 19 & 23 & 11 & 96 \\
\hline 11. & & Ephydridae & Agromyza oryzae & 11 & 32 & 28 & 35 & 15 & 120 \\
\hline 12. & & $\begin{array}{l}\text { Cecidomyiida } \\
\mathrm{e}\end{array}$ & Orselia Oryzae & 19 & 38 & 34 & 42 & 22 & 154 \\
\hline 13. & Orthoptera & Acrididae & Oxya spp & 7 & 12 & 26 & 19 & 5 & 69 \\
\hline 14. & Hemiptera & Pentatomidae & $\begin{array}{l}\text { Scotinophara } \\
\text { lurida }\end{array}$ & 0 & 4 & 11 & 5 & 0 & 20 \\
\hline 15. & Coleoptera & $\begin{array}{l}\text { Chrysomelida } \\
\text { e }\end{array}$ & $\begin{array}{l}\text { Dicladispa } \\
\text { armigera }\end{array}$ & 0 & 1 & 5 & 3 & 0 & 9 \\
\hline 16. & & & $\frac{\text { Leptispa pygmaea }}{\text { Total }}$ & $\begin{array}{c}0 \\
119\end{array}$ & $\begin{array}{c}0 \\
261\end{array}$ & $\begin{array}{c}5 \\
285\end{array}$ & $\begin{array}{c}3 \\
307 \\
\end{array}$ & $\begin{array}{c}1 \\
109\end{array}$ & $\begin{array}{c}9 \\
1104\end{array}$ \\
\hline
\end{tabular}



dibawah ini.

Persentase dari serangga hama yang tertangkap di seluruh lahan percobaan pada fase vegetatif dapat dilihat di Gambar 1

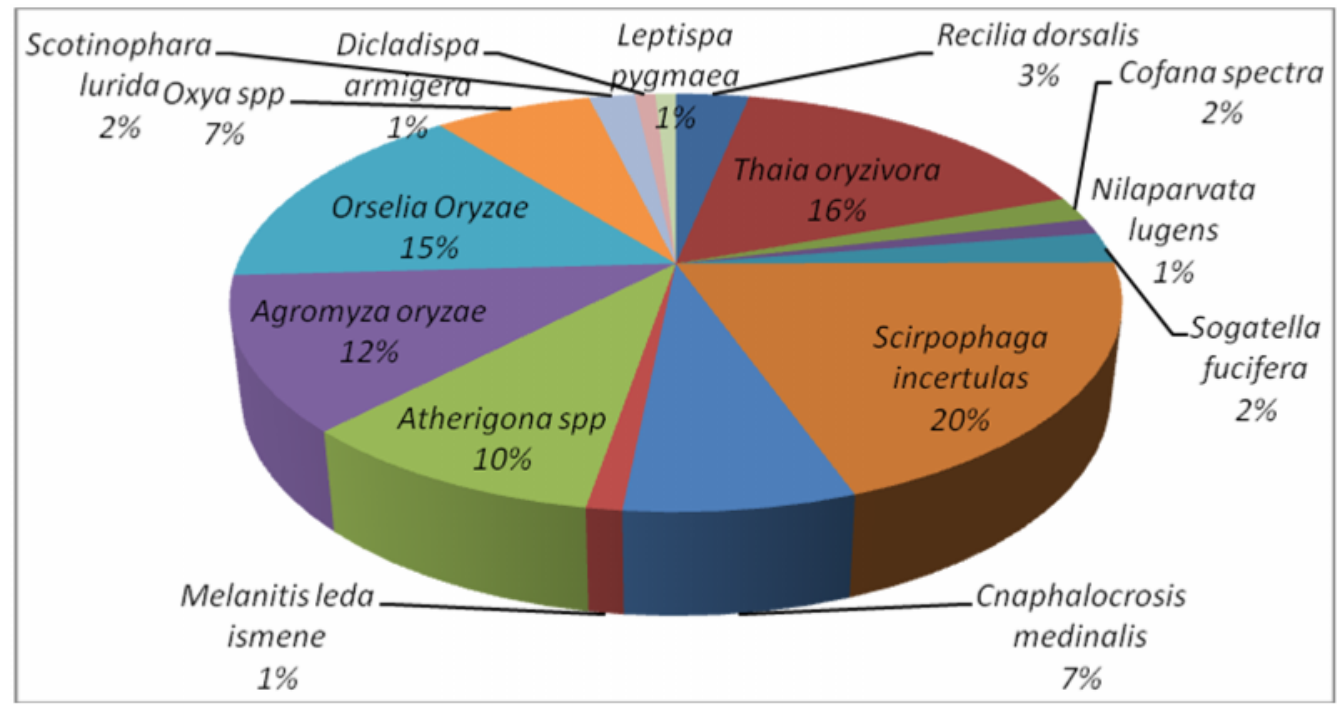

Gambar 1. Persentase Serangga Hama yang Tertangkap pada Fase Vegetatif Tanaman Padi.

Serangga hama yang banyak diperoleh pada lahan padi sawah dataran tinggi pada fase vegetatif yaitu Scirpophaga incertulas yaitu 198 ekor $=20 \%$ (Tabel 1 dan Gambar 1).

Gejala akibat dari serangan S. Incertulas dapat dilihat di Gambar 2. S. incertulas banyak ditemukan di lahan karena kondisi lingkungan yang mendukung untuk perkembangan serangga hama ini.

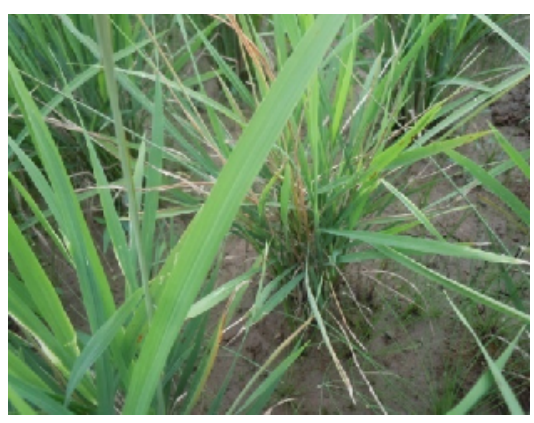

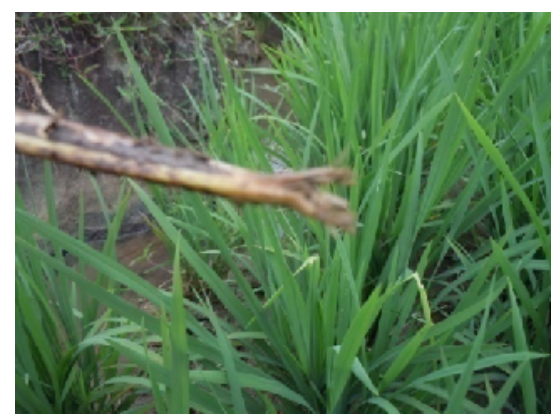

Gambar 2. Gejala Sundep Karena Serangan Scirpophaga incertulas

Serangga hama yang sedikit diperoleh pada lahan padi sawah dataran tinggi pada fase vegetatif yaitu Dicladispa armigera, dan Leptispa pygmaea masing-masing 9 ekor $=1 \%$ (Tabel 1 dan Gambar $1)$.

\section{Serangga Hama yang Tertangkap pada Fase Generatif di Lahan Padi}

Hasil tangkapan dari 5 plot sampel pengamatan lahan percobaan dengan perangkap kuning, cahaya, dan jaring pada fase generative sebanyak 545 ekor seperti pada Tabel 2. 
Tabel 2. Jenis dan Jumlah Serangga Hama yang Tertangkap dengan Perangkap Kuning, Cahaya, dan Jaring pada Lahan Padi Sawah fase Generatif Dataran tinggi di desa Sukawening, Kecamatan Ciwidey.

\begin{tabular}{|c|c|c|c|c|c|c|c|c|c|}
\hline \multirow[t]{2}{*}{ No. } & \multicolumn{3}{|c|}{ Serangga hama } & \multicolumn{6}{|c|}{ Jumlah } \\
\hline & Ordo & Family & Spesies & 1 & 2 & 3 & 4 & 5 & $\sum$ \\
\hline 1. & Homoptera & Cicadellidae & $\begin{array}{l}\text { Nephotettix } \\
\text { virescens }\end{array}$ & 1 & 4 & 4 & 7 & 3 & 19 \\
\hline 2. & & & $\begin{array}{l}\text { Recilia } \\
\text { dorsalis } \\
\end{array}$ & 0 & 4 & 5 & 2 & 1 & 12 \\
\hline 3. & & & $\begin{array}{l}\text { Thaia } \\
\text { oryzivora }\end{array}$ & 3 & 9 & 13 & 26 & 5 & 56 \\
\hline 4. & & & $\begin{array}{l}\text { Cofana } \\
\text { spectra }\end{array}$ & 1 & 1 & 5 & 4 & 2 & 13 \\
\hline 5. & & Delphacidae & $\begin{array}{l}\text { Nilaparvata } \\
\text { lugens }(x x)\end{array}$ & 1 & 0 & 2 & 2 & 0 & 5 \\
\hline 6. & & & $\begin{array}{l}\text { Sogatella } \\
\text { fucifera }\end{array}$ & 0 & 1 & 4 & 3 & 2 & 10 \\
\hline 7. & Lepidoptera & Pyralidae & $\begin{array}{l}\text { Scirpophaga } \\
\text { incertulas }\end{array}$ & 15 & 33 & 31 & 35 & 7 & 121 \\
\hline 8. & & & $\begin{array}{l}\text { Cnaphalocros } \\
\text { is medinalis }\end{array}$ & 3 & 4 & 9 & 12 & 2 & 30 \\
\hline 9. & Diptera & Muscidae & $\begin{array}{l}\text { Atherigona } \\
\text { spp }\end{array}$ & 4 & 6 & 4 & 3 & 3 & 20 \\
\hline 10. & & Ephydridae & $\begin{array}{l}\text { Agromyza } \\
\text { oryzae }\end{array}$ & 2 & 9 & 13 & 15 & 5 & 44 \\
\hline 11. & & $\begin{array}{l}\text { Cecidomyiida } \\
\text { e }\end{array}$ & $\begin{array}{l}\text { Orselia } \\
\text { Oryzae }\end{array}$ & 0 & 3 & 7 & 4 & 3 & 17 \\
\hline 12. & Orthoptera & Acrididae & Oxya spp & 3 & 2 & 13 & 16 & 3 & 37 \\
\hline 13. & Hemiptera & Alydidae & $\begin{array}{l}\text { Leptocorisa } \\
\text { acuta }\end{array}$ & 22 & 39 & 31 & 31 & 21 & 144 \\
\hline 14. & & Pentatomidae & $\begin{array}{l}\text { Nezara } \\
\text { viridula }\end{array}$ & 1 & 3 & 4 & 8 & 1 & 17 \\
\hline
\end{tabular}

NB : Tanda (xx) : Merupakan data penelitian disertasi atas nama : Martua Suhunan Sianipar

Dengan Tim Promotor : Prof.Dr.Entun Santosa,Ir, DR. Drs. RC. Hidayat Soesilohadi, MS, Dr. W.Daradjat Natawigena, Ir., MS

Persentase dari serangga hama yang tertangkap di seluruh lahan percobaan pada fase generatif dapat dilihat di Gambar 3. 


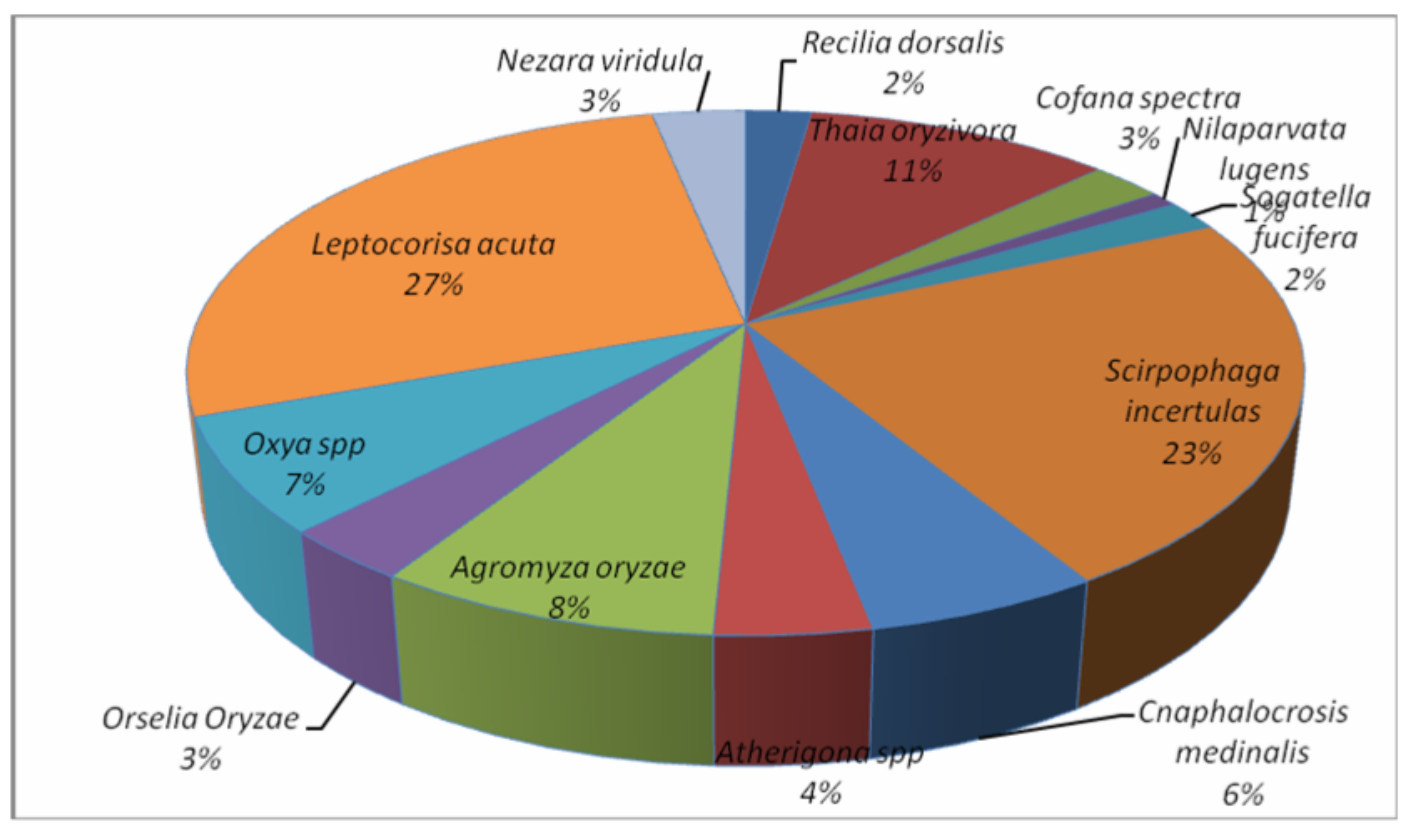

Gambar 3. Persentase Serangga Hama yang Tertangkap pada Fase Generatif Tanaman Padi.

Pada fase generatif serangga hama yang banyak tertangkap yaitu Leptocorisa acuta berjumlah 144 ekor $=27 \%$ (Tabel 2 dan gambar 3). L acuta menyerang tanaman padi saat bulir masak susu sehingga bulir menjadi hampa (Kalshoven, 1981). L. acuta tinggi adalah karena kondisi hujan dengan intensitas rendah, penanaman yang tidak serempak, dan di sekitar lahan banyak terdapat tanaman gulma (Reissig et al., 1985). Gejala Serangan L.acuta dapat dilihat di Gambar 4.

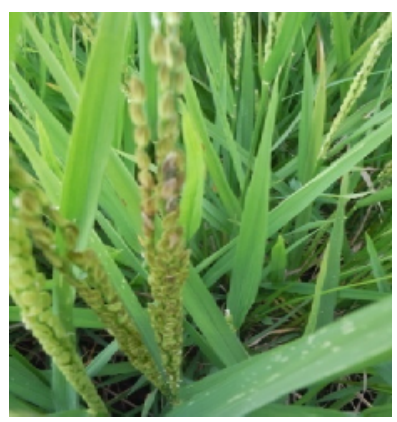

Gambar 4. Gejala Serangan Leptocorisa acuta.

Hama yang sedikit diperoleh pada fase generatif yaitu Nilaparvata lugens yaitu sebanyak 5 ekor $=1 \%$ (Tabel 2 dan Gambar 3). Hal ini diduga karena varietas padi yang ditanam tahan terhadap serangan N. Lugens (BB Padi, 2011).

\section{Perbedaan Populasi Serangga Hama di Fase Vegetatif dan Generatif}

Jenis individu serangga hama yang tertangkap fase vegetatif berbeda dengan yang tertangkap pada fase generatif. Pada fase vegetatif diperoleh 16 spesies serangga hama dan fase generatif diperoleh 14 spesies serangga hama.

Serangga hama yang hanya muncul di fase vegetatif tercatat 4 spesies yaitu Melanistis leda ismene yaitu ulat kepala tanduk hijau. Dicladispa armigera, Leptispa pygmaea dan Scotinophara lurida dan serangga hama yang hanya muncul di fase generatif ada 2 spesies yaitu Leptocorisa acuta dan Nezara viridula.

\section{Indeks Keragaman Serangga Hama pada Fase Vegetatif}

Indeks keragaman serangga hama di lahan padi sawah di Desa Sukawening Kecamatan Ciwidey Kabupaten Bandung pada fase vegetatif dapat dilihat pada Gambar 5. Berdasarkan data tersebut diketahui bahwa indeks keragaman serangga hama di lahan padi sawah pada setiap 
waktu pengamatan selalu berubah-ubah. Perubahan indeks keragaman serangga hama di lahan padi sawah pada setiap waktu pengamatan terjadi karena populasi setiap organisasi pada setiap ekosistem tidak pernah sama dari waktu ke waktu namun terjadi kenaikan dan penurunan (Untung, 2006).

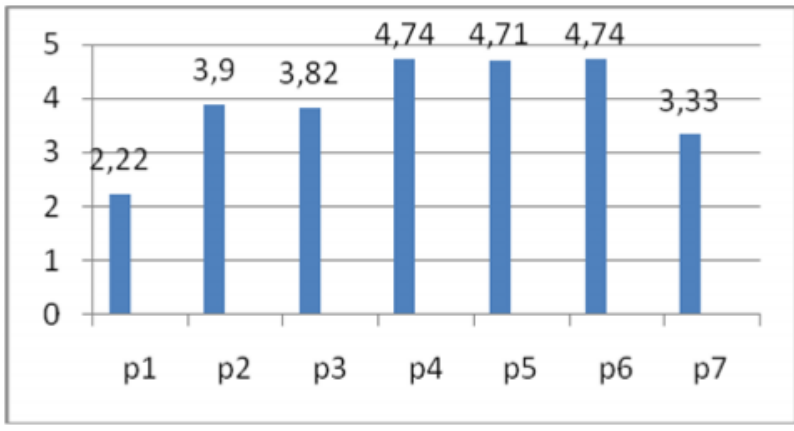

Keterangan : $\mathrm{pN}=$ pengamatan ke $\mathrm{N}$

Gambar 5. Histogram Indeks Keragaman Serangga Hama pada Fase Vegetatif

Indeks keragaman serangga hama pada fase vegetatif tergolong sedang hingga tinggi. Indeks keragaman tertinggi didapatkan pada pengamatan ke 6 yaitu 4,74 (Gambar 5). Pada pengamatan ke 6 tanaman padi sedang berada pada fase vegetatif akhir, pada fase ini morfologi tanaman padi seperti ukuran dan bentuk daun sesuai untuk makanan dan tempat serangga hama meletakkan telur sehingga banyak serangga hama yang menyerang tanaman padi pada fase ini (Untung, 2006).

Pengamatan pertama merupakan pengamatan dengan indeks keragaman terendah yaitu 2,22 (Gambar 5). Pada pengamatan pertama tanaman padi masih berumur 2 minggu. Pada fase ini sedang terjadi pembentukan dan pertumbuhan populasi serangga hama menuju keseimbangan. Hal tersebut menyebabkan jenis serangga hama yang ada belum banyak sehingga keragaman serangga hama juga masih rendah.

\section{Indeks Keragaman Serangga Hama pada Fase Generatif}

Indeks keragaman serangga hama di lahan padi sawah di Desa Sukawening Kecamatan Ciwidey Kabupaten Bandung pada fase generatif dapat dilihat pada Gambar 6.

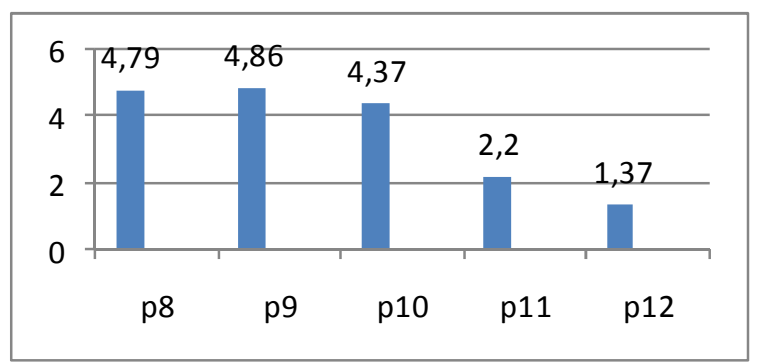

Keterangan : $\mathrm{pN}=$ pengamatan ke $\mathrm{N}$

Gambar 6. Histogram Indeks Keragaman Serangga Hama pada Fase Generatif

Indeks keragaman serangga hama pada fase generatif tergolong sedang hingga tinggi. Indeks keragaman tertinggi didapatkan pada pengamatan ke 9 yaitu 4,86 (Gambar 6). Pada pengamatan ke 9 tanaman padi masuk fase generatif awal dimana pada tahap ini tanaman padi baru membentuk malai. Pada fase ini kondisi tanaman padi sesuai untuk makanan serangga hama. Pada fase ini muncul juga hama baru yang dominan menyerang tanaman padi yaitu Leptocorisa acuta.

Indeks keragaman terendah didapatkan pada pengamatan ke 12 yaitu 1,37 (Gambar 6). Pada tahap ini tanaman padi memasuki fase generatif akhir. Terjadi penurunan populasi karena pada pengamatan ini morfologi padi baik ukuran dan bentuk tidak sesuai lagi bagi serangga hama. Pada pengamatan ini juga tanaman sudah mempunyai ketahanan yang lebih kuat berupa mengerasnya jaringan tanaman sehingga kondisi ini tidak disukai serangga hama. Kondisi di sekitar lahan yang tidak menanam secara serempak memengaruhi keragaman serangga hama karena serangga hama cenderung menyerang tanaman padi yang lebih muda.

\section{KESIMPULAN DAN SARAN}

Kesimpulan

Berdasarkan hasil percobaan yang dilakukan, maka dapat diambil beberapa kesimpulan sebagai berikut :

1. Serangga hama yang banyak diperoleh pada fase vegetatif yaitu Scirpophaga incertulas, Thaia oryzivora, dan Orselia oryzae. Serangga hama yang sedikit diperoleh yaitu Dicladispa armigera, Leptispa pygmaea, dan Melanitis leda ismene dan serangga hama yang banyak 
diperoleh pada fase generatif yaitu Leptocorisa acuta, Scirpophaga incertulas, dan Thaia oryzivora. Serangga hama yang sedikit diperoleh yaitu Nilaparvata lugens, Sogatella furcifera, dan Cofana spectra.

2. Indeks keragaman serangga hama yang diperoleh pada ketiga lahan percobaan dari sedang hingga tinggi. Pada fase vegetatif indeks keragaman tertinggi sebesar 4,74 pada pengamatan ke 6 . Indeks keragaman terendah pada pengamatan ke 1 sebesar 2,22. Pada fase generatif indeks keragaman tertinggi pada pengamatan ke 9 sebesar 4,86. Pada fase ini muncul juga hama baru yang dominan menyerang tanaman padi yaitu Leptocorisa acuta. Indeks keragaman terendah pada pengamatan ke 12 sebesar 1,37. Pada tahap ini tanaman padi memasuki fase generatif akhir. Terjadi penurunan populasi karena pada pengamatan ini morfologi padi baik ketahanan jaringan tanaman, ukuran dan bentuk tidak sesuai lagi bagi serangga hama.

\section{Ucapan terima kasih}

Kami tim peneliti mengucapkan terima kasih kepada semua pihak yang telah memberikan ijin dan membantu kami dalam pelaksanaan penelitian ini. Terima kasih kami sampaikan kepada Yth Rektor Unpad, Dekan Fakultas Pertanian Unpad, Kepala Departemen HPT Faperta Unpad, Kepala Balai Proteksi Tanaman Pangan dan Hortikultura Jawa Barat beserta jajarannya, Pemerintahan Desa Sukawening, Kecamatan Ciwidey, Kabupaten Bandung beserta jajarannya. Semoga kerja sama ini bisa berlangsung selamanya. Amien.

\section{DAFTAR PUSTAKA}

Anonimous. $2008 . \quad$ http:// itswrong.webs.com/indeks.diversitas.pdf. (diakses pada tanggal 2 Januari 2012).
Balai Besar Padi. 2011. http:// bbpadi.litbang.go.id/sarinah.pdf. (diakses pada tanggal 2 Januari 2012).

Buchori, D dan B, sahari. 2000. Keanekaragaman Serangga dan Pengendalian Hayati : Antara Pertanian dan Konservasi Alam. Prosiding simposium Keanekaragaman Hayati Arthropoda pada Sistem Produksi Pertanian Hal : 207 -214

Hill. D. S. 1997. The Economic Importance of Insects. Chapman and Hal. London. Weinheim. New York. Tokyo Melborne. Madras. 395p.

IRRI. 1983. Permasalahan Lapangan Tentang Padi di Daerah Tropika. Los Banos. Laguna. Hal 4-40.

Jumar. 2000. Entomologi Pertanian. Rineka Cipta. Jakarta. Hal 42-51.

Kalshoven. L.G.E. 1981. The Pest of Crops in Indonesia. PT. Ichtiar Baru van Hoeve, Jakarta. Hal 89-112.

Krebs, C. J. 1978. Ecology : Experimental Analysis of Distribution and Abundance. Second edition. Harper \& row publisher. New York etc. 86p.

Odum. E. P. 1971. Fundamental of Ecology. W.B. Sounders. Philadelpia. 64p.

Reissig, W.H., E. A. Heinrichs, J. A. Litsinger, K. Moody, L. Fiedler, T. W. New and A. T. Barrion. 1985. Illustrated Guide to Integrated Pest Managment of Rice in Tropical Asia. International Rice Research Institute, Los Baños, Laguna.Philippines. $89 \mathrm{p}$.

Untung, K. 2006. Pengantar Pengelolaan Hama Terpadu. Gadjah Mada University. Yogyakarta. 